\title{
ANALISIS TES ARGUMENTASI MATERI TERAPUNG DAN TENGGELAM
}

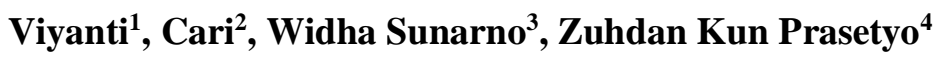 \\ ${ }^{1}$ Program Studi Doktor Pendidikan IPA, Program Pascasarjana, Universitas Sebelas Maret \\ ${ }^{2,3}$ Program Studi Doktor Pendidikan IPA, Program Pascasarjana, Universitas Sebelas Maret \\ ${ }^{4}$ Program Magister Pendidikan IPA, Program Pasacasarjana, Univeristas Negeri Yogyakarta \\ E-mail: ${ }^{1}$ viyanti@student.uns.ac.id; ${ }^{2}$ carinln@yahoo.com; ${ }^{3}$ widhasunarno@gmail.com; \\ ${ }^{4}$ zuhdan@uny.ac.id
}

\begin{abstract}
Abstrak
Tujuan penelitian mengembangkan tes yang berorientasi pada keterampilan argumentasi. Instrumen tes digunakan untuk memetakan kemampuan argumentasi siswa dan pemahaman siswa tentang argumentasi. Instrumen tes berorientasi pada argumentasi dikembangkan berdasarkan skema argumentasi Toulmin. Populasi penelitian adalah siswa SMA kelas XI Kota Bandar Lampung. Sampel menggunakan teknik cluster random sampling untuk 37 siswa. Berdasarkan perhitungan dan analisis statistik item konten tiap elemen perlu diperbaharui lagi dan divalidasi oleh ahli argumentasi ilmiah dan ahli konten materi. Hasil pengembangan tes argumentasi ilmiah ini menjadi landasan untuk menyusun instrumen tes yang lebih lengkap sehingga dapat mengukur semua struktur pendukung komponen argumentasi.
\end{abstract}

Kata kunci: keterampilan argumentasi; materi terapung dan tenggelam

\section{Pendahuluan}

faktor penting $\begin{array}{rr}\text { Keterampilanentasi } & \text { sebagai } \\ \text { keberhasilan } & \text { proses }\end{array}$ pembelajaran memuat, 1) kemampuan mengintegrasikan pengetahuan dan ide, menggambarkan dan mengevaluasi pernyataan (NGA, 2010); 2) kemampuan mengembangkan dan menganalisis pernyataan ilmiah, mendukung pernyataan ilmiah, menjelaskan dan mengevaluasi pernyataan ilmiah (NRC, 2012); 3) menerapkan praktek ilmiah dan mengembangkan cara mempertahankan pernyataan (Lawson, 2003); 4) aspek fundamental dari literasi sains (Driver, Newton, \& Osborne, 2000); dan 5) kemampuan terlibat dalam proses berpikir tingkat tinggi (Conley, 2008). Banyaknya dampak positif keterampilan argumentasi dalam pembelajaran menuntut guru memasukan argumentasi ilmiah pada proses pembelajaran di kelas.

Namun, yang terjadi dilapangan keterampilan argumentasi menjadi sulit untuk dikembangkan disebabkan oleh kemampuan berpikir kritis siswa dan kualitas pembelajaran relatif rendah, sejalan dengan hasil penelitian: 1) Pusat Nasional untuk Statistik Pendidikan
(2012) sebagian besar siswa tidak menguasai keterampilan berpikir tingkat tinggi; 2) Duschl dan Osborne (2002), Erduran dan JimenezAlexandre (2008), dan Osborne, Simon, Christodoulou, Howell-Richardson, \& Richardson (2013) beberapa dekade terakhir kurangnya kualitas pembelajaran argumentasi ilmiah pada kelas sains; 3) Sadler (2004) kesulitan mengajar analisis argumen disebabkan adanya hubungan timbal balik yang kompleks antara isu sosio-ilmiah dan sifat sains. Pembelajaran inovatif merupakan langkah tepat meningkatkan kualitas argumentasi yang didukung penilaian berkualitas. Penelitian ini menyajikan hasil tes kualitas keterampilan argumentasi ilmiah siswa pada materi terapung dan tenggelam.

Skema argumentasi Toulmin (1985) sebagai dasar pengembangan instrumen tes terdiri dari: 1) claim sebagai pusat argumentasi; 2) data pendukung klaim; 3) warrant, hubungan antara data dan claim. 4) backing, kualitas dan jenis alasan; 5) rebuttal, mengidentifikasi pengecualian untuk claim atau claim alternatif; 6) qualifiers, pernyataan pemberi sifat, batas atau kondisi eksplisit yang merupakan bagian dari claim. Skema argumentasi Toulmin mampu mengidentifikasi 
aspek argumentasi yang akan dinilai serta dapat menilai pembenaran suatu argumen selain struktur argumen itu sendiri. Bulgren dan Ellis (2012) mendefinisikan prosedur penilaian argumentasi ilmiah yang dikolaborasikan dengan skema argumentasi Toulmin yaitu, 1) mengidentifikasi claim yang disajikan dalam dokumen tertulis atau kegiatan penyelidikan dan analisa claim untuk qualifiers; 2) mengidentifikasi data, jenis data, dan menilai kualitas data; 3) mengidentifikasi alasan yang menyebabkan claim, jenis penalaran dan menilai kualitas penalaran; 4) mengambil kesimpulan tentang claim, dan menjelaskan alasan yang mendukung hadirnya rebuttal; dan 5) kesimpulan. Skema argumentasi Toulmin yang dikolaborasikan dalam instrumen tes penilaian meliputi prosedur penilaian termasuk perangkat strategis penilaian dengan komponen argumentasi ilmiah sangat efektif dalam pembelajaran sains serta memudahkan dalam mengevaluasi argumentasi siswa.

Banyak tersedia jenis tes untuk mengukur keterampilan berpikir tingkat tinggi, namun konten tes berpikir tingkat tinggi masih bersifat umum dengan menggunakan konten dari sejumlah subjek atau kehidupan seharihari, atau multi-aspek berpikir tingkat tinggi. Merancang tes berorientasi pada argumentasi mengutamakan kegiatan inti praktek sains menjadi kebutuhan tes dimana membantu siswa mengungkapkan pengetahuan selain konten. Instrumen tes keterampilan argumentasi menggunakan skema argumentasi Toulmin (1958) dalam rangka membentuk kerangka kerja analitis dalam menentukan dan memeriksa argumen.

\section{Metode Penelitian}

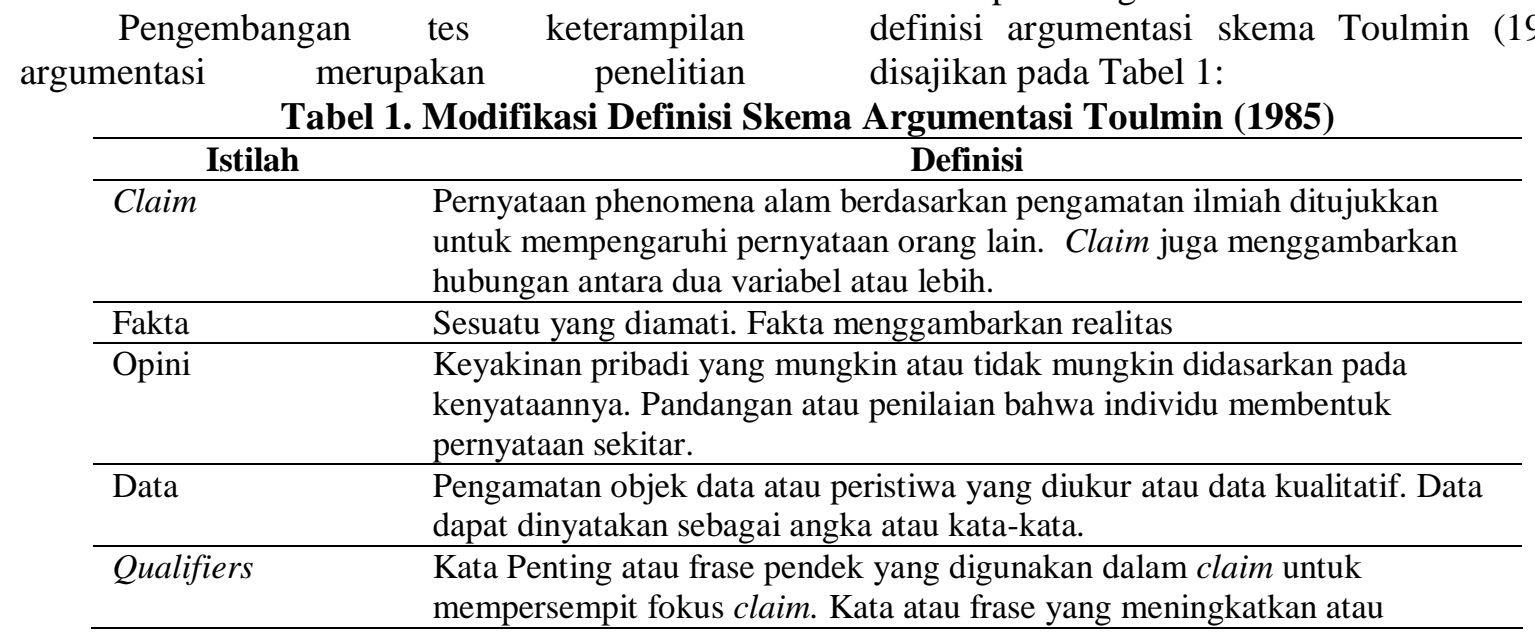

pendahuluan untuk merancang framework kebutuhan assessment berorientasi pada argumentasi. Tujuan lebih luasnya menghasilkan instrumen tes berorientasi pada argumentasi pada pembelajaran inkuiri terbimbing yang berguna dan praktis untuk guru.

Populasi penelitian adalah siswa SMA di Kota Bandar Lampung. Sampel penelitian adalah kelas XI berjumlah 37 orang. Analisis data menggunakan deskritif kualitatif berdasar pada struktur komponen pendukung keterampilan argumentasi.

Instrumen tes untuk mengukur argumentasi dikembangkan menggunakan komponen kunci dari argumentasi skema Toulmin yang modifikasi oleh Frey, Ellis, Bulgren, Hare and Ault (2015) dimaksudkan untuk mengukur: 1) kemampuan membedakan antara klaim, fakta dan opini; 2) kemampuan membedakan antara otoritas, logika dan teori; 3) kemampuan mengidentifikasi qualifiers pada claim; 4) kemampuan membedakan antara sanggahan dan kontra; 5) kemampuan mengevaluasi kekuatan atau kualitas penalaran digunakan ketika menilai claim; 6)kemampuan membedakan antara claim, fakta dan opini, setelah ditambahkan data; dan, 7) kemampuan mengidentifikasi apakah sebuah pernyataan adalah meng-claim atau tidak claim.

\section{Hasil Penelitian}

Bulgren dan Ellis (2014) memodifikasi definisi skema argumentasi Toulmin (1985) dalam rangka menggambarkan struktur komponen penting argumentasi. Modifikasi definisi digunakan dalam penelitian pendahuluan untuk mengembangkan item tes keterampilan argumentasi siswa. Modifikasi definisi argumentasi skema Toulmin (1985) 


\begin{tabular}{ll}
\hline \multicolumn{1}{c}{ Istilah } & \multicolumn{1}{c}{ Definisi } \\
\hline Otoritas & menurunkan kualitas (atau "jumlah ") dari ide atau hal/sesuatu. \\
\hline Logika & $\begin{array}{l}\text { Sebuah sumber informasi terpercaya. Jika claim karena otoritas, berarti } \\
\text { sumber claim bereputasi, ahli atau terpercaya. }\end{array}$ \\
& $\begin{array}{l}\text { Menetapkan sebuah aturan rasional untuk membuat kesimpulan yang wajar } \\
\text { Jika claim karena logika, berarti kesimpulan benar setelah memeriksa } \text { claim } \\
\text { menggunakan pemikiran yang matang dan alasan. }\end{array}$ \\
\hline Teori & $\begin{array}{l}\text { Pernyataan umum terorganisir menjelaskan fenomena alam. Jika } \text { claim } \\
\text { karena teori, itu berarti telah menerapkan ilmiah, penjelasan teknis tentang } \\
\text { bagaimana atau mengapa sesuatu terjadi. }\end{array}$ \\
\hline Rebuttal/Bantahan & $\begin{array}{l}\text { Pernyataan bahwa claim salah berdasarkan bukti dan penalaran. } \\
\text { Sanggahan/bantahan tidak setuju dengan claim, tetapi tidak membuat klaim } \\
\text { baru. }\end{array}$ \\
\hline Argumen kontra & $\begin{array}{l}\text { Claim alternatif berdasarkan penalaran dan bukti. Counter- argumen } \\
\text { mengajukan claim baru yang tidak menyetujui claim pertama. }\end{array}$ \\
\hline Kualitas penalaran & $\begin{array}{l}\text { Sejauh mana bukti dan logika mendukung claim. Penalaran adalah rantai } \\
\text { pikiran atau pernyataan terkait. Setiap rantai penalaran berakhir dengan } \\
\text { kesimpulan. Dengan alasan yang baik, "link" dalam rantai mendukung } \\
\text { kesimpulan. Alasan yang mendasari dapat didasarkan pada otoritas, logika } \\
\text { atau teori. }\end{array}$ \\
\hline
\end{tabular}

Sumber: Bulgren dan Ellis (2014)

Modifikasi definisi skema argumentasi Toulmin (1985) digunakan pada materi terapung dan tenggelam menghasilkan 43 item tes terdiri dari: 1) 6 item tes mengidentifikasi komponen claim, data, opini, dan fakta; 2) 6 item tes mengidentifikasi komponen qualifiers; 3) 6 item untuk mengidentifikasi komponen claim dan non claim; 4) 14 item tes untuk mengidentifikasi komponen teori, logika dan otoritas; 5) 6 item tes untuk mengidentifikasi komponen rebuttal dan countra argument; 6) 6 item tes untuk mengidentifikasi kualitas pernyataan argumentasi kuat atau lemah. Rangkuman hasil tes argumentasi dengan menggunakan modifiksi definisi skema argumentasi Toulmin disajikan dalam bentuk tabel dan disajikan pada Tabel 2 berikut:

Tabel 2. Rangkuman hasil tes argumentasi siswa

\begin{tabular}{lcccc}
\hline \multirow{2}{*}{ Komponen tes } & $\sum$ soal & Mean & SD & Realibilitas \\
\cline { 2 - 5 } & 43 & 0,58 & 4,42 & 0,55 \\
\hline klaim, data, opini dan fakta & 6 & 0,76 & 0,41 & 0,54 \\
\hline qualifiers & 6 & 0,47 & 0,46 & 0,52 \\
\hline klaim dan bukan klaim & 6 & 0,53 & 0,48 & 0,56 \\
\hline teori, logika, dan otoritas & 14 & 0,50 & 0,48 & 0,56 \\
\hline rebuttal dan counter argument & 6 & 0,62 & 0,46 & 0,56 \\
\hline argumentasi kuat atau lemah & 6 & 0,75 & 0,40 & 0,54 \\
\hline
\end{tabular}

Rangkuman hasil perhitungan realibilitas tes keterampilan argumentasi ditampilkan pada Tabel 2. Tingkat kesulitan untuk skala penuh adalah $58 \%$, yang berarti bahwa rata-rata siswa menjawab pertanyaan dengan benar 58\%. Kesulitan pada tiap indikator dari yang terendah ke yang tertinggi adalah $47 \%$ (indikator qualifiers) dan $76 \%$. Tes diberikan kepada siswa sebelum pembelajaran menerapkan argumentasi ilmia (membedakan klaim, data, opini dan fakta). Reliabilitas menggunakan tes Cronbach koefisien alpha, berkategori cukup dengan $\alpha=0,55$. Sebagian besar indikator menunjukkan realibilitas ratarata berkategori cukup.

Komponen keterampilan argumentasi banyak dijawab sempurna oleh siswa pada elemen pertanyaan argumentasi membedakan klaim, data, opini dan fakta. Namun, elemen keterampilan argumentasi lainnya dapat diperbaharui agar dapat lebih diandalkan dengan memasukkan lebih banyak item pernyataannya.

Berdasarkan analisis data hasil penelitian, tes argumentasi ilmiah tampaknya menjadi instrumen yang dapat digunakan untuk menilai keterampilan argumentasi 
ilmiah. Selain itu hasil tes dapat digunakan untuk memetakan elemen keterampilan argumentasi siswa yang perlu dibenahi dengan menggunakan instrumen tes yang telah diperbaharui kembali.

\section{Kesimpulan}

Tes Argumentasi ilmiah sebagai penilaian praktis argumentasi ilmiah untuk siswa SMA. Hal ini dapat ditunjukkan bahwa tes yang digunakan dapat memetakan elemen keterampilan argumentasi siswa. Selain itu tes ini juga memuat 1) konsep dasar terapung dan tenggelam yang tertuang dalam item butir soal telah didefinisikan dan komprehensif , 2) menggunakan definisi skema argumentasi Toulmin sebagai proses menyusun butir soal elemen keterampilan argumentasi, 3) memberikan gambaran struktur untuk memudahkan pengembangan item tes pada materi lain.

Berdasarkan perhitungan statistik item konten tiap elemen perlu diperbaharui lagi dan divalidasi oleh ahli argumentasi ilmiah dan ahli konten materi. Hasil pengembangan tes Argumentasi ilmiah ini menjadi landasan untuk menyusun instrumen tes yang lebih lengkap sehingga dapat mengukur semua struktur pendukung komponen argumentasi.

\section{Daftar Pustaka}

Bulgren, J., Ellis, J., Marquis, J. (2014) The Use and Effectiveness of an Argumentation and Evaluation Intervention in ScienceClasses. Journal of Science Education and Technology.

Conley, D. T. (2008). College knowledge: What it really Takes For Students To Succeed and What We Can Do To Get Them Ready. New York, NY: John Wiley \& Sons.

Driver, R., Newton, P., \& Osborne, D. (2000). Establishing The Norms of Scientific Argumentation In Classrooms. Science Education.

Erduran S, and Jimenez-Alexandre M P (2008). Argumentation In Science Education: Perspectives From Classroom-Based Research. New York, NY: Springer.
Frey, Ellis, Bulgren, Hare, Ault. (2015). Development of a Test of Scientific Argumentation. Electronic Journal of Science Education.

Lawson, A.E. (2003). The Nature and Development of HypotheticoPredictive Argumentation With Implications For Science Teaching. International Journal of Science Education.

National Center for Education Statistics (2012). The Nation's Report Card: Science 2011 (NCES 2012-465). Institute of Education Sciences, U.S. Department of Education, Washington,D.C.

National Governors Association. (2010). Common Core State Standards For English Language Arts \& Literacy In History/Social Studies, Science, and Technical Subjects. Washington, DC:National Governors Association Center for Best Practices and the Council of Chief State School Officers.

National Research Council. (2012). A Framework for K-12 Science Education: Practices, Crosscutting Concepts, and Core Ideas. Washington, DC: National Academies Press.

Sadler, T. D. (2004). Informal Reasoning Regarding Socioscientific Issues: A Critical Review of Research. Journal of Research on Science Teaching.

Osborne, J., Simon, S., Christodoulou, A., Howell-Richardson, C., \& Richardson, K. (2013). Learning To Argue: A Study Of Four Schools and Their Attempt To Develop the Use Of Argumentation as a Common Instructional Practice and Its Impact On Students. Journal of Research in Science Teaching.

Toulmin (1985). The Uses of Argument. Cambridge: Univer- sity Press. 

JPFK, Vol. 2 No. 2, September 2016, hal 89 -92 http://e-journal.ikippgrimadiun.ac.id/index.php/JPFK 